\title{
Attributes of School Leaders towards Achieving Sustainable Leadership: A Factor Analysis
}

\author{
Norlia Goolamally ${ }^{1} \&$ Jamil Ahmad $^{2}$ \\ ${ }^{1}$ Faculty of Science and Technology, Open University Malaysia, Malaysia \\ ${ }^{2}$ Faculty of Education, Universiti Kebangsaan Malaysia, Malaysia \\ Correspondence: Norlia Goolamally, Faculty of Science and Technology, Open University Malaysia, Malaysia. \\ E-mail: nolee@oum.edu.my
}

Received: June 13, 2013

Accepted: February 7, $2014 \quad$ Online Published: February 22, 2014

doi:10.5539/jel.v3n1p122

URL: http://dx.doi.org/10.5539/jel.v3n1p122

\begin{abstract}
A principal plays a very important role in deciding the direction and success of a school. Whether a school is dynamic is dependent upon the skills and abilities of the principal. In order to be excellent, the principal must be in possession of an excellent character. Therefore, the selection and promotion of school principals should be conducted through a meticulous and objective procedure. The entire process must be reviewed in order to ensure the quality and high standard of national education. Selection according to seniority or competency in work performance through evaluation of management and administrative skills, which is the current practice, may not be suitable for the enhancement of the leadership of principals. This study was conducted to identify and affirm the conceptual framework and attributes of school leaders (principals) needed to achieve leadership sustainability and school excellence. The exploratory factor analysis method was employed for the purpose of this study and was implemented in three stages. The sample population comprised primary and secondary school teachers. Through this study, it was found that there were five important traits or attributes which a school leader or principal must possess in order to make a school excellent. These five attributes are: (i) integrity, which has the sub-attributes of being principled and humble; (ii) forward looking, which has the sub-attributes of strategic catalyst and mind motivator; (iii) inspirational, which has the sub-attributes of supportive and influential; (iv) competent, which has the sub-attributes of task competency (there are two components, namely, action-oriented and sociability as well as emotional and spiritual competency); and (vi) self-efficacy.
\end{abstract}

Keywords: leadership, attributes of school leaders, factor analysis

\section{Introduction}

Since the middle of the 20th century, the concept of leadership has been widely researched. More than 350 definitions of leadership have been stated (George \& Jones, 2000) and thousands of empirical researches have been conducted with regard to leadership. However, this concept is still surrounded by ambiguity and it is difficult to distinguish between leaders and non-leaders as well as between effective and ineffective leaders. The definitions of leadership which have been provided mostly involve the aspect of influence, namely, the process whereby a leader influences followers or subordinates to achieve organisational objectives; the process of heading an organisation to achieve organisational objectives; the characteristics of leaders; and leaders as agents of change. There is no universal consensus on the definition of leadership.

According to Dessler (1998), among the characteristics which distinguish between leaders and followers are that leaders:

i. Are more ambitious than followers;

ii. Are prepared to shoulder the responsibilities of an organisation;

iii. Possess honesty and integrity;

iv. Possess a high level of confidence in making decisions and are able to convince others;

v. Determine which mechanisms are suitable for reaching organisational objectives and make the best decisions for organisational excellence; and

vi. Possess knowledge and skills in the area assigned to them. 
In general, a successful organisation has three main components, namely, structure, followers and leaders. Each component plays a role in determining the objectives and success of an organisation. The structure of an organisation provides the direction of the organisation and is the basis upon which interaction and communication could take place. The followers of an organisation respond to the structure and leader. The leader is the one who determines the effectiveness of an organisation by using their characteristics and skills to find the best method to perform an assigned task.

Leadership is a main indicator in determining the success of an organisation. In fact, an authoritative leader is one of the important factors in determining the success of an organisation (Bass, 1990). There are even some who are of the opinion that a society, country or organisation which does not have an authoritative leader would not last long (Locke et al., 1991).

In the institution of a school, the principal is the leader, administrator and manager who implements various functions and therefore, needs to be efficient and intelligent in executing leadership tasks. Leadership of high quality is greatly required for the management and administration of a school in order to produce a quality generation (Musa, 2002). Whether the desired education vision and mission are achieved depend on the efficiency of the principal in managing a school's main resources. Researches on school management have found that schools which attained a high rate of academic success were led by principals with effective leadership qualities (Atan Long et al, 1990; Dunford et al, 2000; Shahril, 2000).

Studies on effective schools have found that the ability of an individual to move ahead in the path towards excellence was influenced by his traits, behaviour and actions (Davis \& Thomas, 1989). Even though a principal may be able to implement and combine diverse leadership styles in the administration and management of a school in order to achieve excellence, they require personal qualities or traits which make them more stable and resilient (Norlia \& Jamil, 2007). A school principal may practise various leadership styles such as educational leadership, transformational leadership and transactional leadership but the practice and enculturation of these leadership styles require a principal to possess these basic qualities - courageous in facing risks and problems as well as in making decisions; has a high level of resilience; and is spirited, trustworthy, empathetic and sympathetic (Smith, 1996). Thus, the leadership efficiency of a principal is determined by his traits and behaviour.

The importance of selecting an effective principal with good personal traits or qualities should be a priority and main focus of education in order to ensure that the nation's school system functions effectively.

Various courses and training can be provided to equip principals with knowledge on management and administration before or after their appointment. However, we must realise that not all who undergo training or attend a course will be able to perform their tasks effectively. Many of them will only perform tasks based on what has been directed by higher authorities without comprehending and integrating actions with belief and confidence towards the responsibility entrusted upon them. Consequently, many of the principals and education leaders produced would be clones in terms of their leadership behaviour.

Specific competencies are required by an effective principal in order to face the various challenges in a school. The phrase "leaders are not born, they can be trained" is quite commonplace; however, the education leaders selected must possess basic qualities which would enable them to undergo training or attend courses on leadership provided by the relevant agencies with efficiency (Norlia \& Jamil, 2007).

At present, rapid changes in the world of education require that the process of recruitment and selection be managed more effectively. At present, this process is based on generic skills in the field of administration and management. However, because the field of education plays an important role in producing human capital that possess the ability to enhance national growth, it is crucial that the recruitment and selection of principals use criteria which are more important than generic skills in the field. The question arises whether success and excellence in technical competency will help a principal succeed in school or there is a need to analyse further the leadership characteristics needed in an era where workers are highly educated, possessing higher degrees or following extension programmes.

\section{Problem Statement}

The progress of a school is usually associated with a principal's leadership and therefore, it may be stated that whether the students of a school acquire a good education is dependent upon good leadership (Shahril, 2000; Peter Neil et al., 2001). An effective principal is required to establish a firm foundation and conducive environment so that an excellent culture of learning may be created. Whether a school rises or falls depends on 
the administration and management of a school, which in turn, depend on the leadership of the principal (Ibrahim, 2000). Fred Hechinger had written about the important role of a principal in bringing a school towards success:

"I have never seen a good school with a poor principal or a poor school with a good principal. I have seen unsuccessful schools turn around into successful ones and regrettably outstanding schools slide rapidly into decline. In each case, the rise or fall could be traced to the quality of the principal". (Davis \& Thomas, 1989, p. 17; Ishak, 2006)

In order to ensure quality in education, principals with potential must be given priority. It is a fact that schools which attain a high rate of academic success are led by principals with effective leadership qualities (Atan Long et al., 1991). Bennis (1989) stated that,

"Leaders do not command excellence. They build excellence. To reach excellence, you must first be a leader of good character. Excellence starts with leaders of good and strong character who engage in the entire of leadership. And the first process is being a person of honourable character." (Bennis, 1989)

Researches on management and administration of effective schools show that their principals have a high initiative to move forward, are smart and target-oriented (Blumberg \& Greenfield, 1986). They have a high level of resilience, are willing to work hard (Ubben et al., 2006) and are proactive (Davies \& Thomas, 1989). They are special individuals with a great personality and are energetic, dynamic, highly committed, proactive, firm and spirited, assertive, possess initiative, responsible, helpful, open-minded, calm and analytical (Persell et al., 1982). These are among the characteristics of an effective leader based on research findings.

From the perspective of national educational development, issues related to the selection of the right school leaders have been discussed since the 1970s. In 1971, a committee assessing the standard of education in schools stated the following in making recommendations on the leadership of school principals and headmasters:

"The Committee recognises that the school principal or head teacher is largely responsible for setting the tone and the standard of educational achievement in the school. We find that there has been no systematic process by which a teacher is prepared or trained for this very important role. The practice has been to leave, as it were, to chance as to how a person would shape up as a head of a school. The problem is also complicated by the constraint of service practice where seniority, either by scheme of service or years of service, has often been used as the criterion for promotion. The technical difficulties of using aptitude and leadership qualities as criteria for promotion have not been resolved. We are of the opinion that it is false to assume that an experienced teacher or even a good teacher would naturally make a good head."

National studies on school leadership (Khuan et al., 2003) found that the leaders of a school which is the hope of the nation possess the characteristics of high resilience, able to adapt well, constantly seek knowledge enhancement and practise lifelong learning, are caring towards the school community, have a clear vision and mission, are dedicated to creating quality work, are able to resolve problems creatively and dare to take risks. The personal traits or qualities of these principals influence the cultural elements of a school such as its surroundings and climate as well as the relationship between the school community and the local community. A study evaluating senior principals which was conducted by the Education Planning and Research Division of the Ministry of Education in 2004 found 63.6 percent of the non-academic school excellence variants were contributed by the personal qualities of principals. This research finding clearly shows that the high level of the personal qualities of principals contributes to the leadership which spurs a school towards excellence.

Khuan et al. (2003) in their study regarding the leadership of schools which are the hope of the nation made the following recommendation:

The selection procedure and the promotion of school principals should be reviewed. Those who are qualified and experienced should be chosen if there are vacancies for principals. The appointment and selection of principals based on seniority is not enough. This is because those who have been chosen might not be able to adapt to the responsibilities assigned. Effective leadership which was explained in this study and also organisational skills and knowledge should be considered as suitable criteria for selection and promotion. The procedure of selection and promotion to the post of principal should be given a firm emphasis because the Ministry of Education has already introduced the promotion of officers through the fast track route. (Khuan et al., 2003)

The selection of education leaders must go through an objective process and be based on international-level qualities if excellence in the world of education is to be achieved. In Western countries, various instruments are used for continuous assessment of leaders, such as Leadership Practice Instrument, Leadership Behaviour 
Description Questionnaire, Leadership Multi-Factor Questionnaire, 360 Degree Performance Evaluation and others.

There are instruments for leaders to make self reports and for subordinates to evaluate leaders so it bears questioning why a similar instrument for the selection and recruitment of principals cannot be formulated. Not only are these instruments used for selection and appointment but the evaluation is used continuously to ensure internal and external client satisfaction towards the organisation. Meanwhile, the promotion method in Malaysia is often based on the recommendations of leaders and annual evaluation; no particular criterion is used to move an individual to a higher position. The question is whether annual evaluation and recommendations by superiors are enough for the selection of a candidate to fill in a position of higher rank.

The process of choosing an effective school leader is difficult because various factors influence leadership effectiveness. However, the selection of a principal should go through a clear and transparent process so that all intentions and planning by the government could be realised successfully. A selection and promotion process which is meticulous and objective could strengthen the national education system as literature reviews show that the success of an education system depends on the school principal (Abdul, 2002). Academicians and policy makers need to seriously look at the selection and appointment of principals so that these fulfil the requirements of the Ministry of Education and those appointed could truly shoulder the responsibilities of a principal in order to enhance national education (Ibrahim, 2006). The Ministry of Education should provide an objective assessment so that principals who truly fulfil the stipulated criteria or standards could be appointed to lead schools in order to carry out the ministry's wish to make Malaysia a country which excels in education.

If the Ministry of Education wishes to make national education excellent, the selection of principals must be objective. The current method of automatic promotion should not be continued as a school leader is very influential and could affect the rise and fall of a school. In addition, the selection of a school principal or leader based on task competency alone is not adequate as the world of education is dynamic and the selected principal must be someone who has mental, emotional and spiritual strength and stability. The failure to identify the right principal or leader could result in a leadership crisis in the national education system. Burns (1978) stated that:

Today, there is crisis in leadership because those who have leadership power comprise men and women who are of low quality and irresponsible. The main issue in this crisis of mediocre leaders is intellectual power. We have failed to identify the essence of leadership which is relevant for this modern time and with that, we are unable to have a consensus even to set a standard to measure, accept or reject a leader. Leadership is most liked by many for observation but it is the most difficult phenomenon to understand in this world. (Burns, 1978, pp. 1-2)

Certain mechanisms are required in order to shortlist candidates for the position of principal based on world-class and quality criteria so that the aspiration to make Malaysia a hub of educational excellence in the eyes of the world can be realised. This aspiration can be effectively and objectively achieved if we can identify and provide a conceptual framework on leadership attributes as well as a valid and reliable instrument to identify the personal traits or qualities of an individual before appointment to the post of principal.

\section{Purpose of Study}

This study is aimed at identifying and confirming the conceptual framework and attributes of school leaders (school principals) towards achieving sustainable leadership and school excellence by using the method of exploratory factor analysis.

\section{Conceptual Framework on Attributes of an Effective Principal towards Achieving Sustainable Leadership}

Discussions on leadership mostly focus on leadership styles based on various leadership theories such as the theories of contingency leadership, behavioural leadership, transformational leadership and transactional leadership. However, discussions on the attributes of an individual are increasingly becoming the focus of discussions on leadership (Block, 1993; Bolman \& Deal, 1992; Kouzes \& Posner, 1988). These attributes are seen as important in maintaining and returning trust, confidence and loyalty in the internal setting of an organisation or in dealing with local and foreign clients.

In efforts to form a conceptual framework on leadership attributes and psychometric instruments which could identify leadership traits or qualities which could be applied in the selection of effective and sustainable school principals, various basic theories on leadership have been combined and integrated so that each perspective on leadership is taken into consideration. The identification of the attributes of effective educational leaders in the context of this study is based on the integration of the credible leader concept by Kouzes and Posner (2002), 
transformational leadership theory by Bass and Avolio (1994), complexity leadership theory by Kotter (1996) and social cognitive theory by Bandura (1986).

An effective school principal is a leader with credibility, integrity and faith in his own abilities. He is capable of effecting change, building a taskforce and developing a work system where each member of the organisation receives equal opportunity to resolve problems with creativity and full commitment by setting a target and a dynamic direction so that organisational objectives could be achieved. Credibility here refers to the quality which enables an individual to be trustworthy and dependable as well as gain people's confidence.

The credibility and self efficacy of leaders determine the effectiveness of their organisations (Kouzes \& Posner, 2002; Chemers et al., 2000). Leaders who are credible and possess a high level of self efficacy are effective leaders and only effective leaders can drive an organisation towards success. Credibility is an attribute which has been studied by Kouzes and Posner since 2002 to determine the personal quality which is sought the most by workers in their leaders. From the 20 qualities listed in the research by Kouzes and Posner, five qualities which were most often placed at the top were honesty, integrity, forward-looking, inspirational and competent. Competency, according to Kouzes and Posner, refer to knowledge and skills competency in work performance. Recent studies on leadership effectiveness are also influenced by emotional intelligence (Goleman, 1996) and self efficacy (Bandura, 1986), so the combination of competency, emotional intelligence and self efficacy is an important element in producing credible leaders. Self efficacy is self assessment of one's ability to organise and carry out the work or actions required in order to achieve a performance target.

Based on the above discussion, an early model of a conceptual framework on the attributes of an effective leader was established. It could be summarised as shown below:

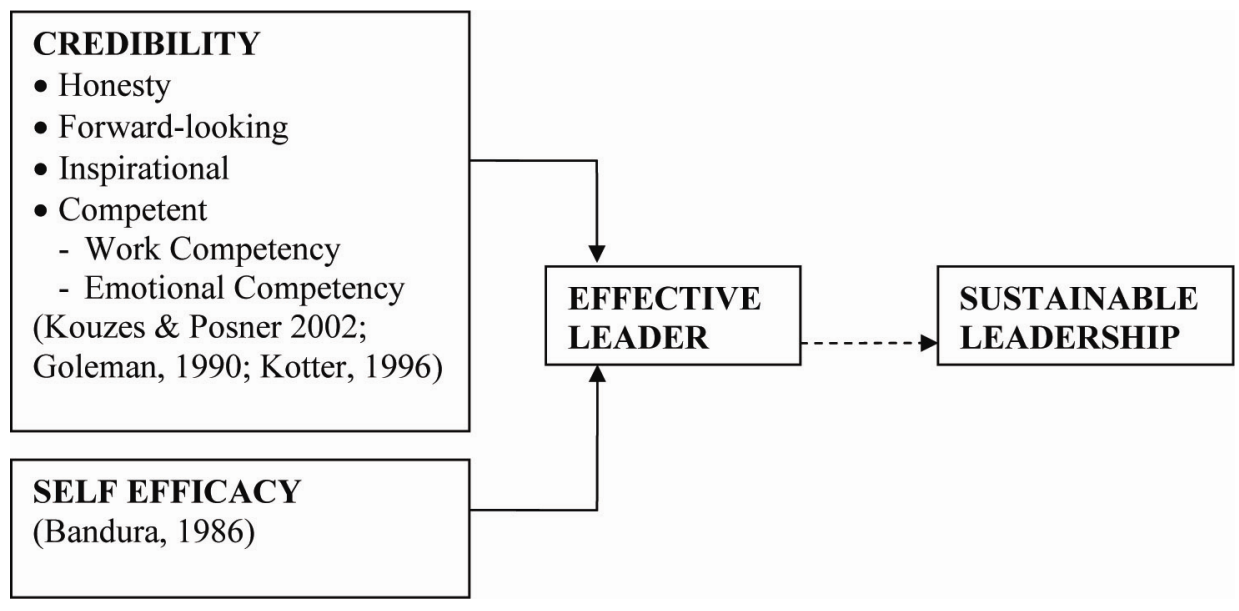

Figure 1. Conceptual framework on attributes of effective leaders towards achieving sustainable leadership

Leadership credibility refers to four main characteristics which are honest, forward-looking, inspirational and competent (Kouzes \& Posner, 1988). According to Fleishman and Harris (1962), honest leaders, who are able to establish mutual trust, respect and a certain warmth and rapport with members of their group, will be more effective. A forward-looking leader is capable of creating an environment where each member of the organisation shares the organisation's vision and objective. Through consensus, communication and persuasion, a leader could promote a vision and encourage teamwork among an organisation's members in order to realise the objectives of the organisation. Vision, based on values and belief, is important for sustaining an organisation. According to Mendez-Morse (1992), there are four important types of vision, namely, organisational vision, futuristic vision, personal vision and strategic vision. Meanwhile, inspiration is the ability to motivate an organisation's members and breathe life into its vision through the use of meaningful and influential language and positive communication (Avery, 2004) as stated by Lao Tzu, Tao and Te Ching, who said that, "True leaders inspire people to do great things, and when the work is done, their people proudly say, We did this ourselves."

Competency refers to a high level of commitment and dedication, emotional intelligence and the courage to take risks. Emotional intelligence refers to the ability of an individual to monitor his own feelings and emotions as well as those of other people (sensitivity, interpersonal skills), and to use this information to guide minds and 
follow-up actions (Salovey \& Mayer, 1990). This covers skills, behaviour, ability and competency to determine attitude, action, thought and communication style (Thornton \& Byham, 1982; Goleman, 1995).

Self efficacy refers to an individual's belief and confidence in his ability and skill to perform a task (Bandura, 1986). Self confidence is a criterion which enables a person to also see other people's abilities. It is expected that the self efficacy of principals would enhance the collective efficacy of workers under their leadership.

The research conceptual framework on the selection of school principals towards achieving sustainable leadership as shown in Figure 1 was validated through expert interviews. This process is important for the purpose of comparing definitions obtained from theories with expert opinion. Data collected through the interview process was analysed and the definition of each construct was formed. The data derived from expert interviews showed they were parallel on the dimensions put forward in the research conceptual framework. A few views and ideas from experts were accepted by the researchers for the purpose of strengthening further the conceptual framework on the selection of school leaders towards achieving sustainable leadership. According to the experts, consideration for principles and discipline in religion and morality enables leaders to move their followers towards the organisational purpose.

Other views by experts are on the activeness and sincerity which come from the soul and spur people to be responsible and committed towards their job. These views are in line with that of Vaughan (2002) on spiritual intelligence. Spiritual intelligence is closely related with behavioural traits such as connectedness, clarity, openness and energy. Based on the analytical findings from the expert interviews, the conceptual framework was revamped and the spiritual aspect was added in the competency attribute as shown in Figure 2.

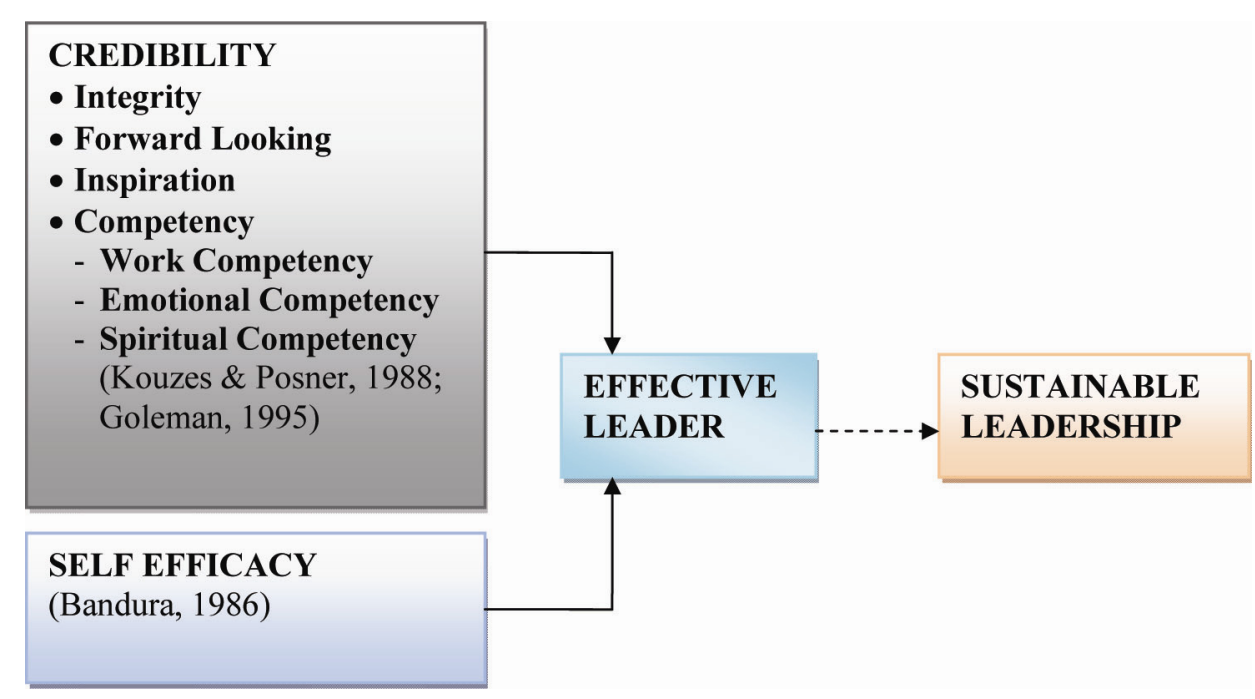

Figure 2. Improved research conceptual framework based on feedback of expert panel

\section{Research Methodology}

\subsection{Research Design}

This research is specifically focused on the development of instruments which have psychometric elements from the aspect of the validity and reliability of the items used. The concepts of reliability and validity are a priority in the development of an instrument or questionnaire. Therefore, in order to get a comprehensive study which will eventually produce an instrument with high validity and reliability, this study uses a combination of qualitative and quantitative designs. The qualitative aspect involves in-depth interviews, analysis of the contents of interview transcripts and the attainment of the reliability value of items built earlier based on the definitions of attributes agreed upon by the expert panel.

Meanwhile, quantitative research involves several stages of data collection for the purpose of testing the reliability and validity of the instruments built. Both the quantitative and qualitative methods are focused on obtaining data collaboration, enabling quantitative and qualitative validation through triangulation (Creswell, 2007). The combination of methods will provide elaboration of information and detailed data as well as 
formulate new thought and give new meaning in a concept. The rationale for using various data collection methods in this study is to enable the researchers to enhance confidence through comprehensive findings and conclusions.

\subsection{Research Instruments}

The research instruments were built by the researchers based on the conceptual framework and the operational definition for each construct which was used in this research. At the early stage of this research, a total of 244 items were developed to measure the constructs of integrity (50 items), forward looking (38 items), inspiration (40 items), task, emotional and spiritual competency (101 items) and self efficacy (15 items). A total of 11 items were built to obtain the respondents' demographic details. The 7-Point Likert Scale was used to obtain school teachers' evaluation of their leaders with a scale of 1 - strongly disagree, 2- disagree, 3 - relatively disagree, 4 neutral, 5- relatively agree, 6- agree, 7 - strongly agree.

\subsection{Research Sample}

This research was conducted with cooperation from several levels of respondents, beginning with the determination of the attribute construct and then item testing. The respondents involved in the implementation of this research were as follows:

i. The first group of respondents comprised research subjects for the process of validating the contents of the instruments and the definition of the attribute constructs used in the formulation of the instruments. They were selected through purposive sampling and comprised seven experts with experience in leadership and measurement.

ii. The second group of respondents was selected based on stratified random sampling according to gender, type of school and location of school. The selection of school teachers was conducted through systematic sampling, namely, through the name list of teachers at the schools involved in the research. Three sets of samples were used for instrument testing as the researchers wanted to create a final instrument with psychometric elements which were stable in terms of reliability and validity. This research sample comprised primary and secondary school teachers from the states of Selangor, Melaka and Negeri Sembilan and the Federal Territories of Kuala Lumpur and Putrajaya. In order to have the items in the questionnaire answered, the ratio of respondents to the items was important. Nunnally (1994) suggested that 10 cases or respondents be obtained for each item while Tabachnick and Fidell (2007) recommended five cases or respondents for each item.

The researchers took the middle path between these two recommendations by using seven cases or respondents per item. As the first test instrument contained 204 items, a total of 1670 respondents were selected from 83 schools for the first stage of testing. Thus, 16 teachers from each school evaluated their principal using the test instrument. The second stage involved 940 teachers from 48 schools while the third stage involved 738 respondents from 39 schools.

\subsection{Procedure for Data Analysis}

Exploratory factor analysis, using SPSS version 17, was conducted to obtain the factor structure which emerged from the items. In order to determine whether exploratory factor analysis could be performed, efforts were made to obtain a value higher than 0.50 through the Kaiser-Meyer-Olkin index of sampling adequacy. This would show that there was a common variance in the data set. In addition, the significance of $(p<0.05)$ for the index value of the Bartlett sphericity test was also investigated to ensure correlation in the data. Next, the Eigen value was tested to determine the factor extraction. The Eigen value measured the variance elaborated by the factors and the total of the square root of the weight on a factor. In this research, an Eigen value with a size of $\geq 1.0$ was used for factor extraction. The researchers employed the technique of principle component analysis by using an orthogonal varimax rotation based on the criteria set by Kaiser (1974) as found in Reinard (2006). The final step was to determine the items which could be accepted or were suitable for a factor. Only items which had weight on a factor were used in this research's exploratory factor analysis.

\section{Research Results}

\subsection{Exploratory Factor Analysis}

At the initial stage of the study, a total of 244 items were formulated to measure the constructs of integrity (50 items), forward looking (38 items), inspirational (40 items), task, emotion and spiritual competency (101 items) and self efficacy (15 items). Based on the opinions of the seven research experts, 40 items were eliminated. As a result, there was a total of 204 items in the research instrument at the initial stage of the study. 
The 204-item instrument was administered to 1670 teachers from 83 schools, so 16 teachers from each school assessed their principal using the test instrument. In this first stage of the exploratory factor analysis, items which had a weight value of two or more different factors were eliminated. A total of 74 items were eliminated and 130 items were retained for administration and testing in the second stage. The 130-item instrument was then administered to 940 teachers selected from 48 schools. In this second stage of the exploratory factor analysis, 26 items were eliminated and 114 items were retained to be administered and tested in the third stage. The items which were eliminated had a weight value of two or more different factors. The 114-item instrument was then administered to 738 teachers selected from 39 schools. In this third stage, 28 items were eliminated and 76 items were retained as instruments for the attributes of school leaders towards achieving leadership sustainability. The distribution of items in the instrument which were eliminated based on the recommendations by the panel of experts and exploratory factor analysis produced a clearer structure and dimension of items (Table 1).

Table 1. Final number of IPPS according to attributes

\begin{tabular}{|c|c|c|c|c|c|c|c|c|}
\hline & & \multirow[b]{2}{*}{$\begin{array}{l}\text { Original } \\
\text { No. of } \\
\text { Items }\end{array}$} & \multicolumn{4}{|c|}{ No. of items eliminated through: } & \multirow[b]{2}{*}{$\begin{array}{l}\text { Total No. of } \\
\text { Eliminated Items }\end{array}$} & \multirow[b]{2}{*}{$\begin{array}{l}\text { Final No. of } \\
\text { Items in IPPS }\end{array}$} \\
\hline Attributes & & & Expert & $1(\mathrm{n}=1670)$ & $\begin{array}{c}\text { EFA } \\
2(n=940)\end{array}$ & $3(\mathrm{n}=738)$ & & \\
\hline \multicolumn{2}{|l|}{ Integrity } & 50 & 11 & 16 & 4 & 5 & 36 & 14 \\
\hline \multicolumn{2}{|c|}{ Forward Looking } & 38 & 5 & 12 & 5 & 4 & 26 & 12 \\
\hline \multicolumn{2}{|l|}{ Inspirational } & 40 & 6 & 9 & 5 & 9 & 29 & 11 \\
\hline \multirow[t]{3}{*}{ Competency } & Task & 63 & 16 & 15 & 10 & 10 & 51 & 12 \\
\hline & Emotion & 20 & 2 & 10 & 0 & 0 & 12 & 8 \\
\hline & Spiritual & 18 & 0 & 5 & 2 & 0 & 7 & 11 \\
\hline \multicolumn{2}{|l|}{ Self Efficacy } & 15 & 0 & 7 & 0 & 0 & 7 & 8 \\
\hline \multicolumn{2}{|l|}{ Total } & 244 & 40 & 74 & 26 & 28 & 168 & 76 \\
\hline
\end{tabular}

\subsection{Results of Exploratory Factor Analysis (EFA) in Third Stage}

Exploratory factor analysis produced a value of 0.969 through the Kaiser-Meyer-Olkin index, which was a measurement index for sampling adequacy. This value is higher than the recommended value of 0.60 (Table 2). The researchers used the criteria set by Kaiser, that is, all components must have the same Eigen value or more than one used for further testing. The value of the Bartlett Sphericity Test was significant $\left(\chi_{(2850)}^{2}=35692.18, \mathrm{p}\right.$ $<0.05)$.

Exploratory factor analysis indicated that 11 factors contributed 60.62 percent to the variance of effective leaders. The percentages of the variants are shown in Table 3.

Table 2. Kaiser-Meyer-Olkin measurement value and Bartlett's test of Sphericity

\begin{tabular}{lll}
\hline Kaiser-Meyer-Olkin & Measure of Sampling Adequacy & $\mathbf{. 9 6 9}$ \\
\hline Bartlett's Test of Sphericity & Approx. Chi-Square & 35692.185 \\
& Df & 2850 \\
& Sig. & .000 \\
\hline
\end{tabular}


Table 3. Exploratory factor analysis value for sub-attributes of effective leaders through analysis of principle components and varimax rotation

\begin{tabular}{lll}
\hline Sub-Attributes & Items & $\begin{array}{c}\text { Percentage } \\
\text { of Variance }\end{array}$ \\
\hline Strategic Catalyst & $\mathrm{b} 27, \mathrm{~b} 23, \mathrm{~b} 24, \mathrm{~b} 25, \mathrm{~b} 22, \mathrm{~b} 26, \mathrm{~b} 20, \mathrm{~b} 28, \mathrm{~b} 21$ & 8.69 \\
Spiritual Competency & $\mathrm{b} 88, \mathrm{~b} 89, \mathrm{~b} 87, \mathrm{~b} 92, \mathrm{~b} 86, \mathrm{~b} 94, \mathrm{~b} 90, \mathrm{~b} 95, \mathrm{~b} 91$, & 8.47 \\
& $\mathrm{~b} 93, \mathrm{~b} 96$, & \\
Action Orientation & $\mathrm{b} 59, \mathrm{~b} 58, \mathrm{~b} 61, \mathrm{~b} 60, \mathrm{~b} 57, \mathrm{~b} 62$, & 7.45 \\
Motivator & $\mathrm{b} 55, \mathrm{~b} 441, \mathrm{~b} 44, \mathrm{~b} 52, \mathrm{~b} 54, \mathrm{~b} 42, \mathrm{~b} 40$ & 6.52 \\
Sociability & $\mathrm{b} 68, \mathrm{~b} 66, \mathrm{~b} 67, \mathrm{~b} 71, \mathrm{~b} 69, \mathrm{~b} 70$, & 5.04 \\
Self Efficacy & $\mathrm{b} 102, \mathrm{~b} 1104, \mathrm{~b} 101, \mathrm{~b} 103, \mathrm{~b} 100, \mathrm{~b} 99, \mathrm{~b} 98, \mathrm{~b} 97$ & 4.99 \\
Humility & $\mathrm{b} 14, \mathrm{~b} 13, \mathrm{~b} 10, \mathrm{~b} 15, \mathrm{~b} 11, \mathrm{~b} 16, \mathrm{~b} 17$ & 4.56 \\
Principled & $\mathrm{b} 4, \mathrm{~b} 3, \mathrm{~b} 2, \mathrm{~b} 5, \mathrm{~b} 6, \mathrm{~b} 7, \mathrm{~b} 18$ & 4.44 \\
Emotional Competency & $\mathrm{b} 82, \mathrm{~b} 81, \mathrm{~b} 85, \mathrm{~b} 80, \mathrm{~b} 83, \mathrm{~b} 84, \mathrm{~b} 79, \mathrm{~b} 78$ & 4.08 \\
Influential & $\mathrm{b} 49, \mathrm{~b} 48, \mathrm{~b} 46, \mathrm{~b} 47$ & 3.79 \\
Mind motivator & $\mathrm{b} 32, \mathrm{~b} 33, \mathrm{~b} 31$ & 2.58 \\
Total percentage of variance & & 60.62 \\
\hline
\end{tabular}

\section{Discussion}

Through exploratory factor analysis, it has been found that there are five important attributes which must be inherent in a school leader or principal in order to spur a school to excel and to create sustainable leadership. These five attributes are integrity, forward looking, inspirational, competency and self efficacy.

Leaders with the attribute of integrity are honest, trustworthy and sincere and their words and actions are trusted. In addition, they are transparent, just and, as much as possible, show congruence between their feelings, thoughts, actions and words. Integrity covers personal qualities such as self respect, loyalty and honesty towards oneself and others. Leaders with self respect focus on who they really are, what they know and what they do so that these can provide the right direction for their followers. Integrity involves characteristics of an individual who possesses honesty which indirectly obtains the trust of those surrounding him. Leaders with integrity do as they say (walk the talk), possess characteristics their followers could emulate, have high moral values and enjoy the loyalty of followers because of their stellar personal characteristics. Fleishman and Harris (1962) said:

"Leaders who are able to establish mutual trust, respect and a certain warmth and rapport with members of their group will be more effective."

The attribute of integrity has two sub-attributes, namely, principled and humble. A principled leader is firm yet understanding, resolute yet just, always careful and practises transparency. Meanwhile, humility is the attribute of a leader who exhibits noble characteristics such as not arrogant, not egoistic, courteous and respectful towards others.

A forward-looking leader is capable of promoting the growth of an organisation by instilling work spirit, motivation and a shared vision in his followers by setting strategic and visionary work and direction as well as using the potential of every individual in the organisation. A forward-looking leader could create an environment each member of the organisation has one organisational vision and objective. The leader could also build aspirations in the organisational vision through consensus, communication and persuasion of the organisational members to work together as a team to achieve organisational objectives. Vision based on value and trust is important for sustaining an organisation. According to Mendez-Morse (1992), there are four important types of vision, namely, organisational vision, futuristic vision, personal vision and strategic vision.

The forward-looking attribute has two sub-attributes, namely, strategic catalyst and mind motivator. Leaders who have the attribute of strategic catalyst dare to take risks, change the status quo, make paradigm shifts and view challenges as opportunities. They are quick to conceptualise and visualise ideas and are analytical and systematic in solving problems. Leaders who are mind motivators seek to reach high targets for themselves or 
their organisations, spurring the members of their organisations to be courageous in discussing intellectual issues.

The attribute of inspiration is a leadership characteristic which could arouse the spirit of organisation members to move forward, beyond what is expected or assigned. An inspirational leader knows how to connect the self concepts of the organisation members to the leader's vision. When leaders get to know their organisation members, they are able to motivate them to work for the success of the organisation. Inspirational leaders use soft skills to capture the hearts of the organisation members to work with full trust and confidence for the progress of the organisation. Such leaders stimulate the spirit of each individual to work for the organisational vision. Thus, inspiration refers to leaders' ability to give life to the organisational vision and inspire members through meaningful and powerful language as well as positive communication (Avery, 2004).

The attribute of inspiration has two sub-attributes, namely, motivator and influential. Motivator refers to leaders who are capable of building organisation members' confidence in the work which needed to be done. These leaders are clear about the work which needs to be performed, are skilled in capturing the hearts of staff so that they continue striving and are courageous in facing changes. Meanwhile, influential leaders are skilled in pulling followers to move forward together with them, spurring them with motivating words so that they have initiative and never giving up in providing them with guidance.

The competency attribute has three sub-attributes, namely, work competency, emotional competency and spiritual competency. Leaders with work competency are committed to excellence, dedicated, focused, dare to take risks, are proactive and set high standards in efforts to achieve excellence. A leader with work competency is a leader with the skill to use diverse strategies and leadership management techniques effectively to develop organisation members towards achieving excellence. Meanwhile, emotional competence is the ability of a leader to manage himself through realisation and emotional control in all situations, to set aside negative emotions for the sake of preserving ties with other individuals in the organisation and to be caring and understanding towards the needs and differences of each individual. Emotional competency refers to the ability of an individual to monitor his feelings and emotions and those of others (sensitivity, interpersonal skills), and remain calm and composed for the purpose of using the information at hand to guide his thinking and next course of action (Salovey \& Mayer, 1990; Thornton \& Byham, 1982; Goleman, 1995).

Men make history, and not the other way around. In periods where there is no leadership, society stands still. Progress occurs when courageous, skilful leaders seize the opportunity to change things for the better.

Spiritual competency is the ability of a leader to integrate and make his feelings (inner life), involving his mind and spirit, concordant with outer feelings (working life). He has the ability to see from various perspectives in order to increase organisational tranquillity.

A leader with self efficacy knows his abilities and usually has the trust to evaluate and appreciate the efforts and resilience of other individuals in the organisation. According to Bandura (1986), self efficacy is an inner characteristic which enables a person to consider his ability to organise and take actions to reach the stipulated goals.

\section{Conclusion}

This research has reached the conclusion that there are five important traits or attributes which a school leader or principal should possess for a school to achieve excellence and for sustainable leadership be created. These five attributes are: (i) integrity, which has the sub-attributes of being principled and humble; (ii) forward looking, which has the sub-attributes of strategic catalyst and mind motivator, (iii) inspirational, which has the sub-attributes of supportive and influential; (iv) competent, which has the sub-attributes of task competency (there are two components, namely, action-oriented and sociability as well as emotional and spiritual competency) and (vi) self-efficacy. 


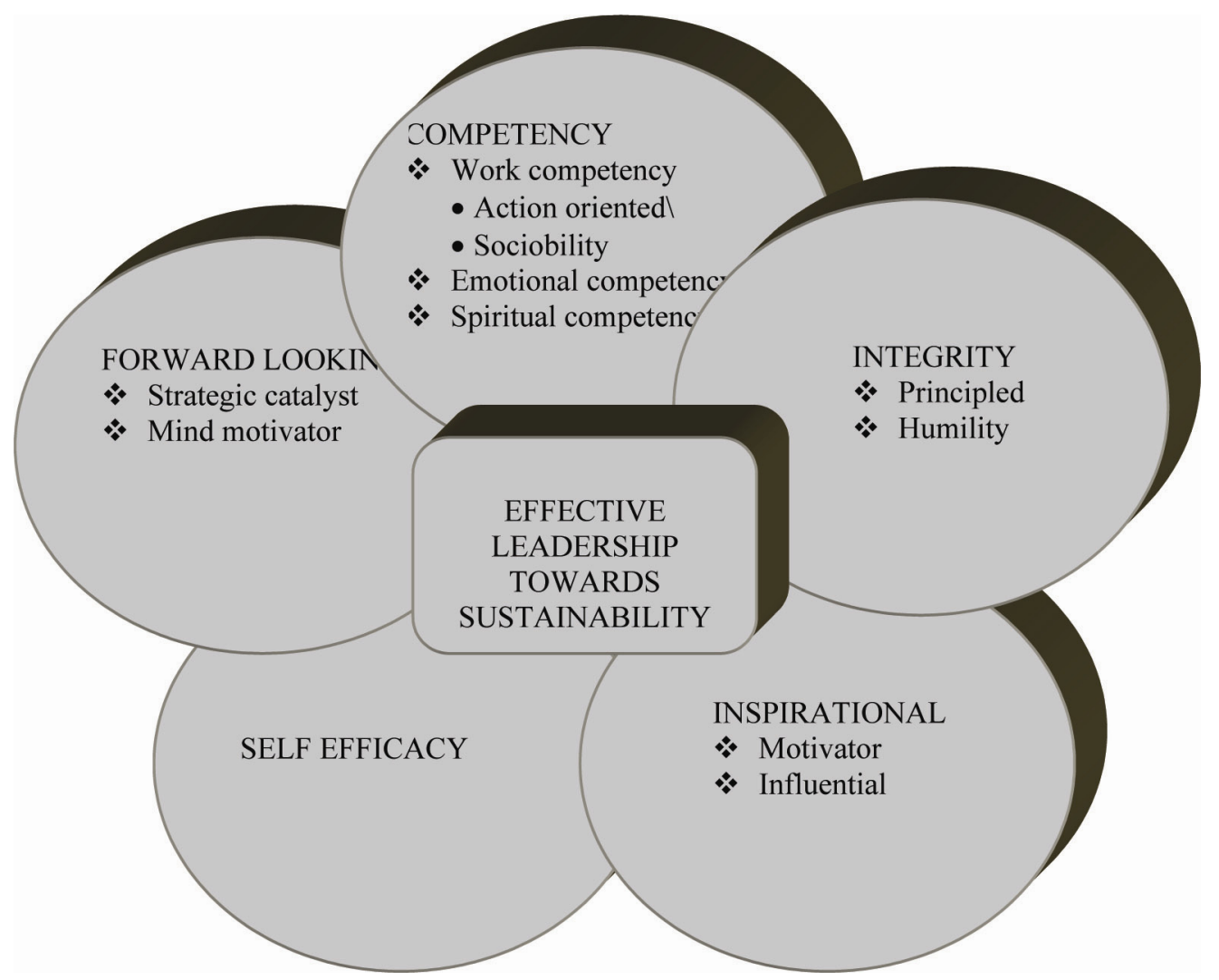

Figure 3. Attributes of school leaders towards achieving sustainable leadership

\section{References}

Abdul, S. A. (1998). Fokus pengurusan pendidikan. Kuala Lumpur: Kementerian Pelajaran Malaysia.

Atan, L. I., Abdul, A. S., Mohd, N. L., Mohd, S. N., Nik, A. H. I., Ratnawati, A., \& Rosnani, H. (1991). Faktor-faktor yang menyumbang kepada peningkatan kemajuan sekolah-sekolah: Kajian kes. Kuala Lumpur, Universiti Islam Antarabangsa Malaysia.

Avery, G. C. (2004). Understanding Leadership. Sage Publications.

Bass, B. M., \& Stogdill. (1990). Handbook of leadership. New York: The Free Press.

Bass, B. M. (1990). Handbook of leadership. Theory, research and managerial application. New York: The Free Press.

Blumberg, A., \& Greenfield, W. (1986). The effective principal: perspectives on school leadership. Allyn and Bacon Inc.

Block, P. (1993). Stewardship: Choosing Service over Self-Interest. San Franscisco, CA: Berrett-Koehler Publishers Inc.

Bolman, L. G., \& Deal, T. E. (1992). Leading and Managing: Effects of context, culture, and gender. Educational Administration Quarterly, 28(3), 314-329. http://dx.doi.org/10.1177/0013161X92028003005

Burns, J. M. (1978). Leadership. New York: Harper \& Row.

Cosley, D. L., \& Todd, R. (1991). Human relations in organization. Saint Paul: West Publishing Company.

Davis, G. A., \& Thomas, M. A. (1989). Effective schools and effective teachers. Boston.

Dessler, G. (1998). Management: Leading people and organisation in the $21^{\text {st }}$ century. New Jersey: Prentice Hall. 
Dessler, G. (1998). Management: Leading people and organisation in the $21^{s t}$ century. Done in Organizations. (San Francisco: Jossey-Bass, 1987).

Dunford, J., Fawcett, R., \& Bennett, D. (2000). School leadership. London: Kogan Page.

George, J. R., \& Jones, G. R. (2000). Essentials of managing organisational behaviour. Upper Saddle River: Prentice Hall.

Goleman, D. (1995). Emotional Intelligence. New York: Bantam Books.

Ishak, S. (2004). Apakah Yang Tertulis Dalam Khazanah Tulisan Ilmiah Tentang Tret, Tingkah Laku Dan Tindakan Yang Diperlukan Untuk Menjadi Seorang Pengetua Yang Berkesan. Kertas yang dibentangkan dalam Seminar Nasional Pengurusan Dan Kepimpinan Pendidikan Ke-12 2004.

Kouzes, J. M., \& Posner, B. Z. (1992). Credibility. San Francisco: Jossey-Bass.

Kouzes, J. M., \& Posner, B. Z. (1988). Development and Validation of the Leadership Practices Inventory. Educational and Psychological Measurement, 48, 483-496.

Kouzes, J. M., \& Posner, B. Z. (1988). Relating Leadership and Credibility. Psychological Reports, 63, 527-530. http://dx.doi.org/10.1177/0013164488482024

Kouzes, J. M., \& Posner, B. Z. (2002). The leadership challenge. San: Allyn and Bacon Inc. http://dx.doi.org/10.2466/pr0.1988.63.2.527

Locke, E. A., Kirkpatrick, S., Wheeler, J. K., Schneider, J., Niles, K., Goldstein, H., ... Chan, D. (1991). The essence of leadership: The four keys to leading successfully. New York: Laxington Books.

Musa, M. (2002). Teks ucapan perasmian persidangan pengurusan pendidikan pengetua-pengetua sekolah menengah Malaysia. Kuala Terengganu.

Musa, M. (2002). Teks ucapan perasmian persidangan pengurusan pendidikan National Conference On The Principalship di National Institute of Education. Institut Aminuddin Baki.

Norlia, G., \& Jamil, A. (2007). Kepimpinan Cemerlang: Antara Tret, Tingkah laku atau Gaya Kepimpinan? Prosiding Seminar Kebangsaan Isu-Isu Pendidikan Negara Ke-Tiga. ESSET, Bangi. Fakulti Pendidikan, UKM.

Persell, C. H., Cookson, P. W. Jr., \& Lyons, H. (1982). Effective principals: What do we know from various educational literatures? Paper presented at the National Conference on the Principalship, Convened by the National Institute of Education, Washington.

Smith, R. (1995). Introduction to education: Successful school management. London: Cassell.

Stogdill, R. M. (1974). Handbook of leadership: A survey of theory and research. New York: The Free Press.

Ubben, G. C., \& Hughes, L. W. (1987). The principal: Creative leadership for affective schools. Wells Avenue, NM: Allyn and Bacon.

Wood, R., \& Bandura, A. (1989). Impact of Concepts of Ability on Self-Regulatory Mechanisms and Complex Decision-Making. Journal of Personality and Social Psychology, 56(3), 407-415. http://dx.doi.org/10.1037/0022-3514.56.3.407

\section{Copyrights}

Copyright for this article is retained by the author(s), with first publication rights granted to the journal.

This is an open-access article distributed under the terms and conditions of the Creative Commons Attribution license (http://creativecommons.org/licenses/by/3.0/). 